\title{
ABALONE (HALIOTIS SQUAMATA) ANESTHESIA WITH ETHANOL ON GRADING PROCESS
}

\author{
Fanni Norma Aprilia* \\ Fisheries and Marine Biotechnology, University of Airlangga, Indonesia \\ Soeprijanto Agoes, Fadholi M. Rasyid \\ Faculty of Fisheries and Marine Science, University of Brawijaya, Indonesia \\ *E-mail: normaapriliafanni@gmail.com
}

\begin{abstract}
An abalone is a group of marine molluscs that have high economic value. To increase abalone production, such cultivation needs to be done considering that abalone production still dominating. However, there are still obstacles in the cultivation which is the high mortality rates on the grading process of juvenile abalone. The fatality occurs due to the traditional grading process by gouging abalone to separate abalone that is attached to the substrate. The use of ethanol as an anesthetic material is expected to minimize the mortality and increase the survival rate of abalone. In this study, the use of ethanol by $30 \mathrm{ml} / \mathrm{L}$ as an anesthetic material can separate the abalone from its substrate 447.67 seconds faster than the dose of $10 \mathrm{ml} / \mathrm{L}$. However, the $30 \mathrm{ml} / \mathrm{L}$ dose also showed the lowest survival rate of $86.67 \%$. The best recovery test is at $10 \mathrm{ml} / \mathrm{L}$ with the fastest recovery time of 143.33 seconds which has a high survival rate of $98.33 \%$. The success of anesthesia by using ethanol in this study can also be done in the grading process of abalone seed and can minimize death due to the traditional grading process.
\end{abstract}

\section{Key words}

Abalone, anesthesia, ethanol, Haliotis squamata.

Abalone or Kerang Mata Tujuh is one of the snail species that can be found in Indonesia and included in the group of marine molluscs (Litaay) [1]. The development of abalone cultivation continues to be improved due to the high selling price in the domestic market which reaches IDR $300.000 / \mathrm{kg}$ [2]. Besides the United States and EU countries, there are several abalone main markets in Asia such as China, Hong Kong, Korea, Japan, and Singapore. However, the majority of world abalone production is still dominated by natural catches. In 2002, it is estimated that the world abalone production reaches 22.600 tons of which only about 8.600 tons are produced from cultivation activities [3].

As a newly developed species, the efforts to increase abalone production with cultivation activities still have technical and technological obstacles. One of which is the high mortality rates during the grading process. This occurs when the juveniles are removed from the substrate to the enlargement area. The separation between the abalone and the substrate is carried out by gouging which can cause injury and death to the abalone [2].

Therefore, an anesthesia is done to minimize the injury thus it could have high life opportunity. An anesthesia is given as a tranquilizer so that it can cause loss of movement, balance, awareness, and consciousness [4].

\section{MATERIALS AND METHODS OF RESEARCH}

The materials used were abalone seeds $(1.5-2.5 \mathrm{~cm})$, ethanol, basket, 10-liter fiber tub, spatula, stopwatch, and ruler. This research was conducted in April to May 2014 in Musi Village, Gerokgak District, Buleleng Regency, Bali.

The sampling of $1.5-2.5 \mathrm{~cm}$ abalone seeds was performed by choosing the seed which has good quality. Then, the sample was placed in a basket that was used as a sticking 
substrate. The characteristics of a good abalone seed are sensitive to external response, strongly stick to the substrate if touched, shrunk and harden if soaked on fresh water, will quickly move if returned to the sea, non-broken shell or misshapen, and no injury to the body or abalone meat.

The anesthesia medium used was ethanol on each treatment: A $(10 \mathrm{ml} / \mathrm{L}), B(20 \mathrm{ml} / \mathrm{L})$ and $C(30 \mathrm{ml} / \mathrm{L})$. Whereas, in the control, the abalone separation from the substrate was done by gouging.

Each dose of ethanol was dissolved in seawater in a fiber tub and placed in a basket that has been plastered with abalone. After that, the duration of the abalone to detach from the basket was calculated with a stopwatch. Once it detached from the basket, the abalone was immediately rinsed by inserting the basket into a fiber tub containing seawater without ethanol. Then, the duration until the abalone stick back to the basket was calculated.

The duration of abalone separation from the substrate begins when the basket was placed into the tub containing anesthetic material. The calculation was done by using this following formula:

$$
\mathrm{Lb}=W_{t}-W_{o}
$$

Where: $L b=$ the latent duration of the anesthetic; $W_{t}=$ the duration of the unconsciousness; $\mathrm{W}_{\mathrm{o}}=$ the duration of the treatment.

The position of the abalone that is detached from its substrate will be reversed so that the calculation of the duration of the recovery began when the abalone turned the body to its original position and re-attached to the substrate.

$$
\mathrm{Wp}=t_{1}-t_{o}
$$

Where: $W p=$ the duration of unconsciousness; $W_{t}=$ the start of unconsciousness; $W_{0}=$ the duration of consciousness.

The post-anesthesia maintenance was done and the survival rate of the abalone was calculated with a formula as follows:

$$
\mathrm{SR}=\frac{N_{t}}{N_{o}} \times 100 \%
$$

Where: $\mathrm{SR}=$ survival rate $(\%) ; \mathrm{N}_{\mathrm{t}}=$ number of individuals who survive; $\mathrm{N}_{\mathrm{o}}=$ the initial number of individual tested.

\section{RESULTS OF STUDY}

The Start of Unconsciousness:

Table 1 - The start of abalone unconsciousness

\begin{tabular}{|c|c|}
\hline Treatment & Duration (second) \pm SD \\
\hline A & $525 \pm 24.25^{\mathrm{a}}$ \\
\hline B & $112.33 \pm 8.74^{\mathrm{b}}$ \\
\hline C & $77.33 \pm 11.37^{\mathrm{C}}$ \\
\hline
\end{tabular}

Different superscripts showed a significant difference $(p<0,01)$.

The study shows the duration of the abalone which begins to be unconscious by using ethanol as an anesthetic material. The fastest time of abalone to separate from the substrate was at treatment $C$ (ethanol $30 \mathrm{ml} / \mathrm{L}$ ) with 77.33 seconds while the longest time was at treatment $A$ (ethanol $10 \mathrm{ml} / \mathrm{L}$ ) with 525 seconds. This shows that the higher the dose of ethanol, the faster the abalone to separate from the substrate. In the control treatment, the duration of the abalone to detach from the substrate was not count because it is done by gouging. The start of abalone unconsciousness can be seen in Table 1. 
Recovery Duration:

Table 2 - Duration of abalone recovery

\begin{tabular}{|c|c|}
\hline Treatment & Duration (second) \pm SD \\
\hline Control & $125.33 \pm 14.19^{\mathrm{a}}$ \\
\hline A & $143.33 \pm 32.87^{\mathrm{a}}$ \\
\hline B & $210.67 \pm 18.72^{\mathrm{b}}$ \\
\hline C & $362.67 \pm 70.24^{\mathrm{C}}$ \\
\hline
\end{tabular}

Different superscripts showed a significant difference $(p<0,01)$.

The fastest duration of abalone recovery was in control treatment with 125.33 seconds while in the anesthesia treatment, the fastest recovery was in treatment $A$ (ethanol $10 \mathrm{ml} / \mathrm{L}$ ) with 143.33 seconds. The longest duration of abalone recovery was in the $C$ treatment (ethanol $30 \mathrm{ml} / \mathrm{L}$ ) with 362.67 seconds. This suggests that the higher the dose of ethanol as an anesthetic, the longer the duration of abalone recovery. The duration of abalone to become unconscious can be seen in Table 2 above.

Survival Rate:

Table 3 - The survival rate of the abalone post-anesthesia

\begin{tabular}{|c|c|}
\hline Treatment & Survival Rate $(\%) \pm$ SD \\
\hline A & $98.33 \pm 2.87^{\mathrm{a}}$ \\
\hline B & $95 \pm 5.00^{\mathrm{a}}$ \\
\hline C & $86.67 \pm 2.87^{\mathrm{b}}$ \\
\hline Control & $85 \pm 5.00^{\mathrm{b}}$ \\
\hline
\end{tabular}

Different superscripts showed a significant difference $(p<0,01)$.

The highest survival rate of the abalone was found in treatment $A(10 \mathrm{ml} / \mathrm{L}$ ethanol) by $98.33 \%$ and the least survival rate was in control treatment by $85 \%$. Meanwhile, in anesthesia treatment, the lowest survival rate was found in treatment $\mathrm{C}$ by $86.67 \%$. This suggests that the higher the dose of the ethanol, the lower the abalone survival rate. The abalone post-anesthesia survival rate can be seen in Table 3.

\section{DISCUSSION OF RESULTS}

Increasing the concentration of ethanol as an anesthetic material can lead to accelerated unconsciousness time of an organism's seed because the process of anesthetic substance absorption by the blood becomes more quickly. The substance of anesthesia that has been absorbed into the blood vessels will be brought to the central nervous system of the brain and spinal cord (central nervous system or CNS). Anesthetic agents that have reached the central nervous system will block the dopamine postsynaptic receptors which also inhibit the release of dopamine and suppress the central nervous system that will cause sedation effects, muscle relaxation, as well as decrease the activities of organisms that are stimulated from the external which then lead to organisms fainting [5].

The recovery treatment after the giving of anesthesia is immersion which the organism is placed in clean water (free of anesthesia). Although recovery can be done by various mechanisms, it is advisable to transfer the organism to a new water-filled container so that the organism's metabolite can be excreted into water through gills and/or skin [6].

The death of abalone in post-anesthetic is suspected due to the water that is soluble with anesthetic material so that it resulted in a decrease in the respiration rate of the organism. The condition causes an anxious and makes the organism to always try come to the surface to get oxygen. A decrease in the respiration rate causes the loss of all sensors in the body as a result of the decrease in nerve function thus blocking action and conducting nerve impulses. Furthermore, it is also explained that anesthetic materials will disrupt the ionic balance in the brain of fish seed either directly or indirectly. This occurs because of the 
decrease in the concentration of $\mathrm{K}^{+}$cations and the increase of $\mathrm{Na}^{+}, \mathrm{Fe}^{3+}$, and $\mathrm{Ca}^{2+}$ cations. Then, this disruption will affect the work of motor neurons and respiratory system [5].

\section{ACKNOWLEDGEMENTS}

The author would like to thank Airlangga University as a place where the author could study as a master student and Brawijaya University as a place where the author could study as a scholar student.

\section{REFERENCES}

1. Litaay, M., Rahmatullah, H. Setyabudi, \& M. S. Hassan. 2011. Dampak Minyak Pelumas terhadap Pertumbuhan Awal Abalon Tropis Haliotis asinina L. Unpublished Thesis. Universitas Hasanuddin.

2. Hamzah, M.S., S.A.P. Dwiono, \& S. Hafid. 2012. Pertumbuhan dan Kelangsungan Hidup Anak Siput Abalon Tropis Haliotis asinina dalam Bak Beton pada Kepadatan Berbeda. Jurnal Ilmu dan Teknologi Kelautan Tropis. 4(2) : 191-197.

3. Rusdi, I., A. Hanafi., B. Susanto, \& M. Marzuqi. 2010. Peningkatan Sintasan Benih Abalon Haliotis squomata di Hatchery melalui Optimalisasi Pakan dan Lingkungan. Balai Besar Riset Perikanan Budidaya Laut.

4. Coyle, S.D., R.M. Durborow., \& J. H. Tidwell. 2004. Anesthetics in Aquaculture. Southern Regional Aquaculture Center. SRAC Publication no. 3900.

5. Saskia, Y., E. Harpeni \& T. Kadarini. 2012. Toksisitas dan Kemampuan Anestetik Minyak Cengkeh (Sygnium aromaticum) terhadap Benih Ikan Pelangi Merah (Glossolepis incisus). Aquasains. Jurnal IImu Perikanan dan Sumberdaya Perairan. 83-87.

6. Neiffer, D.L and Andrew, M.S. 2009. Fish Sedation, Anesthesia, Analgesia, and Euthanasia: Considerations, Methods, and Types of Drugs. ILAR Journal. 50(4): 349360. 